\title{
Effect of attachments and palatal coverage of maxillary implant overdenture on stress distribution: a finite element analysis
}

\author{
Jong-Hee Park', Yuan-Kun Wang'1, Jeong-Jin Lee', Yeon-Hee Park1, Jae-Min Seo1, Kyoung-A Kim²* \\ 'Department of Prosthodontics, School of Dentistry and Institute of Oral Bio-Science, Jeonbuk National University, Jeonju, \\ Republic of Korea \\ ${ }^{2}$ Department of Dentistry, School of Medicine, Eulji University, Daejeon, Republic of Korea
}

Purpose: The purpose of this study was to evaluate the effect of attachments and palatal coverage on stress distribution in maxillary implant overdenture using finite element analysis. Materials and Methods: Four maxillary overdenture 3-D models with four implants placed in the anterior region were fabricated with computer-aided design. 1) Ball-F: Non-splinted ball attachment and full palatal coverage, 2) Ball-P: Non-splinted ball attachment and U-shaped partial palatal coverage, 3) Bar-F: Splinted milled bar attachment and full palatal coverage, 4) Bar-P: Splinted milled bar attachment and U-shaped partial palatal coverage. Stress distribution analysis was performed with ANSYS workbench $14.100 \mathrm{~N}$ vertical load was applied th the right first molar unilaterally and maximum stress was calculated at the implant, peri-implant bone and mucosa. Results: The use of the ball attachment showed lower maximum stress on implant and peri-implant bone than the use of the milled bar attachment. But it showed contrary tendency in the mucosa. Regardless of attachment, full palatal coverage showed lower maximum stress on implant, peri-implant bone and mucosa. Conclusion: Within the limitation of this study, ball attachment improved stress distribution on implant and periimplant bone rather than milled bar attachment in maxillary implant overdenture. Also, full palatal coverage is more favorable in stress distribution. (J Dent Rehabil Appl Sci 2020;36(2):70-9)

Key words: implant overdenture; attachment; finite element analysis

\begin{abstract}
서론
상악 완전 무치악 환자에서 임플란트 피개의치 수복 은 전통적인 총의치 수복에 비해 유지와 안정이 우수하 여 환자의 저작 능력을 향상시키고, 심리적 안정을 주는 좋은 치료방법이다..$^{1-3}$ 또한, 다수의 임플란트를 식립하면 말굽형(U-shaped) 주연결장치를 이용하여 구개부위 피 개를 최소화 할 수 있다. ${ }^{4}$ 하지만, 골흡수 및 상악동 함기 화로 인한 부족한 골량, 불량한 골질로 인해 상악 임플란 트 피개의치는 하악 임플란트 피개의치에 비해 높은 실
\end{abstract}

*Correspondence to: Kyoung-A Kim

Assistant Professor, Department of Dentistry, School of Medicine, Eulji University, 771-77 Gyeryong-ro, Jung-gu, Daejeon, 34824, Republic of Korea Tel: +82-42-611-3486, Fax: +82-42-611-3776, E-mail: dentka@eulji.ac.kr Received: March 17, 2020/Last Revision: May 5, 2020/Accepted: May 21, 2020
패율을 보인다..$^{5-7}$ 상악 임플란트 보철물의 성공률을 높 이기 위해서는 해부학적 조건 외에도 적절한 임플란트의 수와 길이, 응력분산에 유리한 유지장치의 선택, 교합력 과 비기능적 습관 등의 생역학적 관점에 대한 고려도 필 요하다. ${ }^{8}$

임플란트 피개의치의 생역학적 안정성을 위해서는 모 든 구성요소에 적절하게 응력이 분산되도록 설계해야 한 다. 임플란트 주위골에 과도한 응력이 집중되면 임플란 트와의 골유착이 파괴되며, 임플란트 상부 구조물이나 매식체에 응력이 집중되면 지대주의 나사 풀림이나 파

Copyright@ 2020 The Korean Academy of Stomatognathic Function and Occlusion. (c) It is identical to Creative Commons Non-Commercial License. 
절 또는 임플란트의 찢어짐 등이 일어날 수 있다. ${ }^{9,10}$ 이에 Mericske-Stern 등 ${ }^{4}$ 은 상악 임플란트 피개의치를 위해 다 음과 같은 치료 지침을 제시하였다. 첫째, 임플란트는 가 능한 많을수록 좋으며 최소 4 개를 식립해야 한다. 둘째, 임플란트는 가능한 표준형인 직경 $4.1 \mathrm{~mm}$, 길이 $10 \mathrm{~mm}$ 이상을 식립해야 한다. 셋째, 전체 악궁에 걸쳐 균등하게 분포해서 식립해야 하며 종종 상악동 거상술을 피하고자 상악동 전방부에 식립할 수 있다. 또한, 유지장치로는 응 력분산을 위해 바(bar) 유지장치 사용을 추천하였다. 그 러나, 상악 임플란트 피개의치에서 볼(ball) 유지장치는 추천되지 않으며, 사용 시 임시 수복의 성격을 띠며 이때 구개부분을 완전히 피개해야 한다고 하였다.

상악 임플란트 피개의치에서 응력 분산을 위한 유지장 치 선택에 대해 많은 연구가 존재하지만 아직 논쟁 중이 다. 여러 연구에서 볼 유지장치를 사용한 경우에 바 유지 장치보다 더 큰 임플란트 주위 골 소실을 보였으며, $3,11,12$ 임플란트를 견고하게 연결 고정하는 바 유지장치의 사용 을 추천하였다. ${ }^{4,13}$ 반대로 다른 광탄성 연구 ${ }^{14,15}$ 와 유한요 소분석 연구 ${ }^{16}$ 에서는 분리된 볼 또는 Locator ${ }^{\circledR}$ 유지장치 의 사용이 연결고정된 바 유지장치보다 임플란트와 임플 란트 주위 골에 낮은 응력집중을 보였으며, 볼과 같이 완 압 성분을 가진 유지장치는 의치에 가해지는 힘을 흡수 하여 임플란트로 응력이 전달되는 것을 줄여준다고 하였 다. ${ }^{17}$ 하악 임플란트 피개의치에서 유지장치가 응력분포 에 미치는 영향에 관해서는 많은 연구 ${ }^{15,16,18}$ 가 진행되었으 나 상악 피개의치의 유지장치 선택에 있어 지침이 될 수 있는 연구는 아직 부족하다.

또한, 상악 의치의 구개를 피개하지 않을 경우 미각, 촉 각과 같은 구강감각과 발음, 저작 등의 구강 기능이 더욱 증진된다고 하였다. ${ }^{19-21}$ 그러나 상악 임플란트 피개의치 의 응력분포에서 구개 피개는 중요하다. Palmqvist 등 ${ }^{22}$ 은 임플란트 피개의치의 장기적인 성공을 위해서는 구개 를 피개하는 것이 중요하다고 했으며, Ochiai 등 $^{14}$ 은 광 탄성 실험을 통해 구개를 피개하지 않는 경우 임플란트 주위 골에 응력이 더욱 집중됨을 보고하였다.

따라서 본 연구의 목적은 3차원 유한요소분석법을 통 해 상악동 전방부에 4 개의 임플란트를 식립하여 수복된 상악 임플란트 피개의치에서 유지장치의 종류, 구개 피 개의 여부가 임플란트, 임플란트 주위 골 그리고 무치악 치조점막으로의 응력분포에 미치는 영향을 알아보고자 함이다.

\section{연구 재료 및 방법}

3차원 computer-aided design (CAD) 프로그램(CATIA 5.0, Dassault Systems ${ }^{\circledR}$, Vélizy-Villacoublay, France)을 이용해 상악골, 임플란트, 유지장치 그리고 피개의치 모 형을 설계하였다(Fig. 1 - 4).

상악은 한국인 무치악 악궁의 평균 ${ }^{23}$ 을 참고해 장경 $49.19 \mathrm{~mm}$, 폭경 $63.49 \mathrm{~mm}$ 로 하였다(Fig. 2). 점막은 구 개 중앙부위는 $1.5 \mathrm{~mm}$, 치조골 부위는 $3 \mathrm{~mm}$ 두께로 설 정하였으며 ${ }^{24}$ 점막 아래로 $1.5 \mathrm{~mm}$ 두께의 피질골을 설 정하고 나머지 부분은 해면골로 설계하였다(Fig. 1). 직 경 $4.0 \mathrm{~mm}$, 길이 $10 \mathrm{~mm}$ 임플란트(Superline, Dentium, Seoul, Korea) 4개를 상악동 전방부(양측 측절치와 견치 사이 그리고 제 1 소구치와 제 2 소구치 사이에 각각 위치시 켰다(Fig. 2). 볼 유지장치는 임플란트와 동일 제조사의 미니볼 지대주(BAB352018, Dentium)를 이용하였다. 바 유지장치는 임플란트의 견고한 연결 고정을 위해 높이 $2.5 \mathrm{~mm}$, 두께 $3 \mathrm{~mm}$ 직육면체 모양의 밀드 바(milled bar)

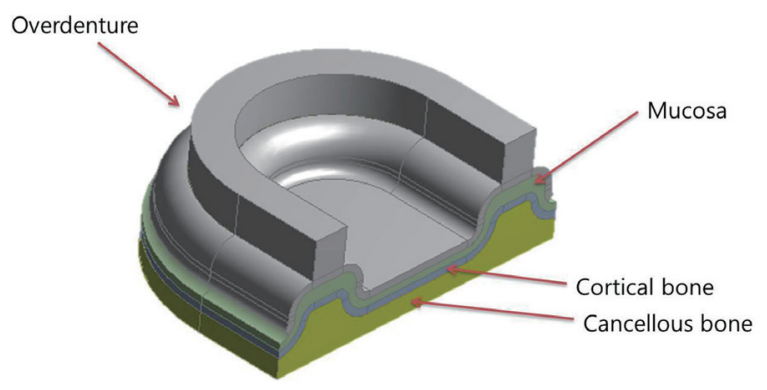

Fig. 1. 3-D model of maxilla and overdenture.

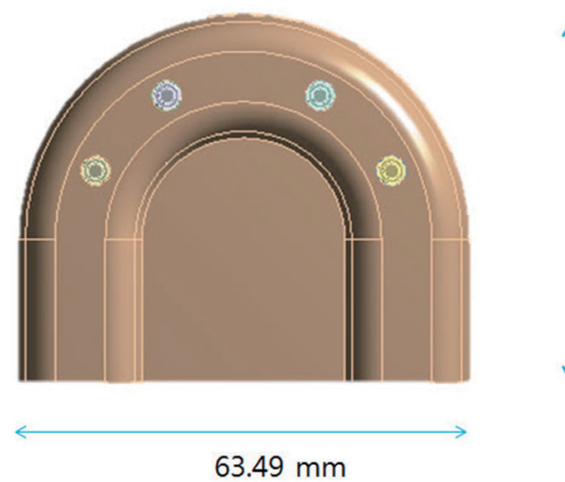

$49.19 \mathrm{~mm}$

Fig. 2. Dimensions of the ridge and location of implants. 
A

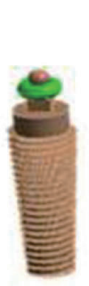

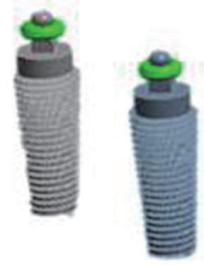

B

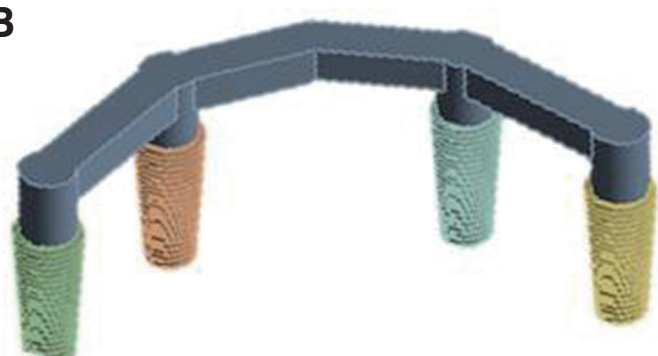

Fig. 3. 3-D models of implant and attachment system. (A) Ball attachment, (B) Milled bar attachment.

A

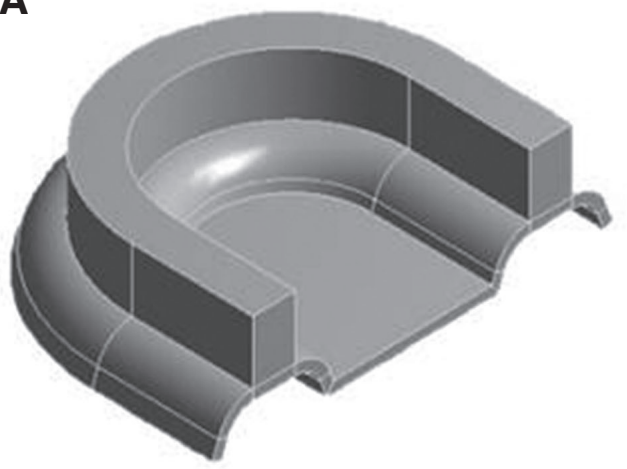

B

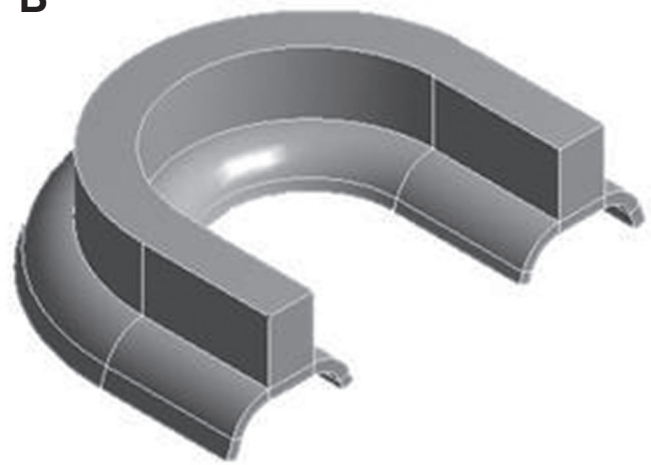

Fig. 4. 3-D models of Maxillary overdentures. (A) Full palatal coverage, (B) Partial palatal coverage.

를 설계하였으며 피개의치의 움직임을 허용하기 위해 밀 드 바와 피개의치 사이에 $0.5 \mathrm{~mm}$ 의 수직적 공간을 부여 하였다(Fig. 3). 상악 피개의치는 구개를 피개하는 경우와 말굽형(u-shape design)과 같이 피개하지 않는 경우로 나 누어 설계하였으며, 모두 금속구조물 없이 단일 아크릴 레진으로 구성하였다(Fig. 4).

유지장치 종류와 피개의치의 구개 피개 유무를 조합하 여 다음과 같이 4 개의 실험군을 구성하였다.

(1) Ball-F: 볼 유지장치를 사용하고 구개를 피개한 군

(2) Ball-P: 볼 유지장치를 사용하고 구개를 피개하지 않은 군

(3) Bar-F: 바 유지장치를 사용하고 구개를 피개한 군

(4) Bar-P: 바 유지장치를 사용하고 구개를 피개하지 않은 군
유한요소분석 프로그램(ANSYS Workbench 14, ANSYS Inc., Canonsburg, USA)을 사용하여 메싱(meshing) 작 업과 응력분석을 시행하였다. 유한요소분석을 위해 각 가상모델은 약 60 만개의 노드(node)와 약 40 만개의 엘 레멘트(element)로 나누어졌다(Table 1). 임플란트와 볼 유지장치 구성성분의 물성치(elastic modulus와 poisson's ratio)는 제조사로부터 제공받았으며, 다른 구성성분의 물성치는 선학들의 연구를 참고하였다(Table 2). ${ }^{17,18,25}$ 상 악의 모든 구성요소와 임플란트의 경계는 접착되었다고 설정하였으며 피개의치와 점막의 경계는 현실적인 재현 을 위해 피개의치가 점막 위에서 마찰을 가지고 운동하 는 마찰접촉조건(마찰계수 0.3)을 부여했다. ${ }^{26}$ 고정조건 으로 상악골 바닥면을 기준면으로 삼고 이 면을 모든 방 향에 대해 고정시켰다. 마지막으로, 모든 재료가 등방성,

Table 1. Number of nodes and elements of the finite element model (unit: ea)

\begin{tabular}{ccccc}
\hline & Ball-F & Ball-P & Bar-F & Bar-P \\
\hline Nodes & 625,539 & 609,980 & 615,244 & 599,255 \\
Elements & 421,440 & 411,756 & 415,183 & 405,266 \\
\hline
\end{tabular}


Table 2. Material properties

\begin{tabular}{lrc}
\hline Materials & $\begin{array}{c}\text { Young's } \\
\text { modulus } \\
(\mathrm{MPa})\end{array}$ & $\begin{array}{c}\text { Poisson } \\
\text { ratio } \\
(\mathrm{\nu})\end{array}$ \\
\hline Cancellous bone & 1,370 & 0.30 \\
Cortical bone & 13,700 & 0.30 \\
Mucosa & 3.4 & 0.45 \\
Overdenture (Acrilic resin) & 3,000 & 0.35 \\
Implant & 105,000 & 0.34 \\
Ball Abutment & 105,000 & 0.34 \\
O-ring & 3.57 & 0.50 \\
Ball attachment metal cap & 113,000 & 0.34 \\
Milled bar (Co-Cr) & 218,000 & 0.33 \\
\hline
\end{tabular}

등질성 그리고 선형 탄성을 가지고 있다고 가정하였다. 하중 조건은 편측 저작을 가정하여 우측 제 1 대구치의 중 심와에 수직방향으로 $100 \mathrm{~N}$ 의 정적하중을 가하였다. 유 한요소분석 프로그램을 통해 각 실험군의 임플란트, 임 플란트 주위 골 그리고 점막의 응력 분포를 관찰하였으 며 최대 응력값을 기록하였다.
Table 3. Maximum equivalent von Mises Stresses (MPa)

\begin{tabular}{crcc}
\hline Group & Implant & Peri-implant bone & Mucosa \\
\hline Ball-F & 4.61 & 1.16 & 0.41 \\
Ball-P & 5.44 & 1.39 & 0.58 \\
Bar-F & 25.52 & 6.85 & 0.27 \\
Bar-P & 28.41 & 7.63 & 0.32 \\
\hline
\end{tabular}

\section{결과}

임플란트, 임플란트 주위 골 그리고 점막의 응력분포 양상은 모든 실험군에서 비슷한 경향을 보였다. 모든 실 험군의 각 구성요소에서 측정된 최대 응력값은 Table 3에 나타냈다. 임플란트에서는 부하측 최후방 임플란트 원심 구개측 경부에서 최대 응력값을 보였고, 임플란트 주위 골에서는 부하측 최후방 임플란트 주위의 원심구개측 피 질골에서 최대 응력값을 보였다. 또한, 점막에서는 부하 측 최후방 치조제에서 최대 응력값을 보였다(Fig. 5 - 7).

유지장치의 종류에 따른 응력분포는 구개피개 유무와 관계없이 볼 유지장치를 사용한 실험군의 임플란트와 임
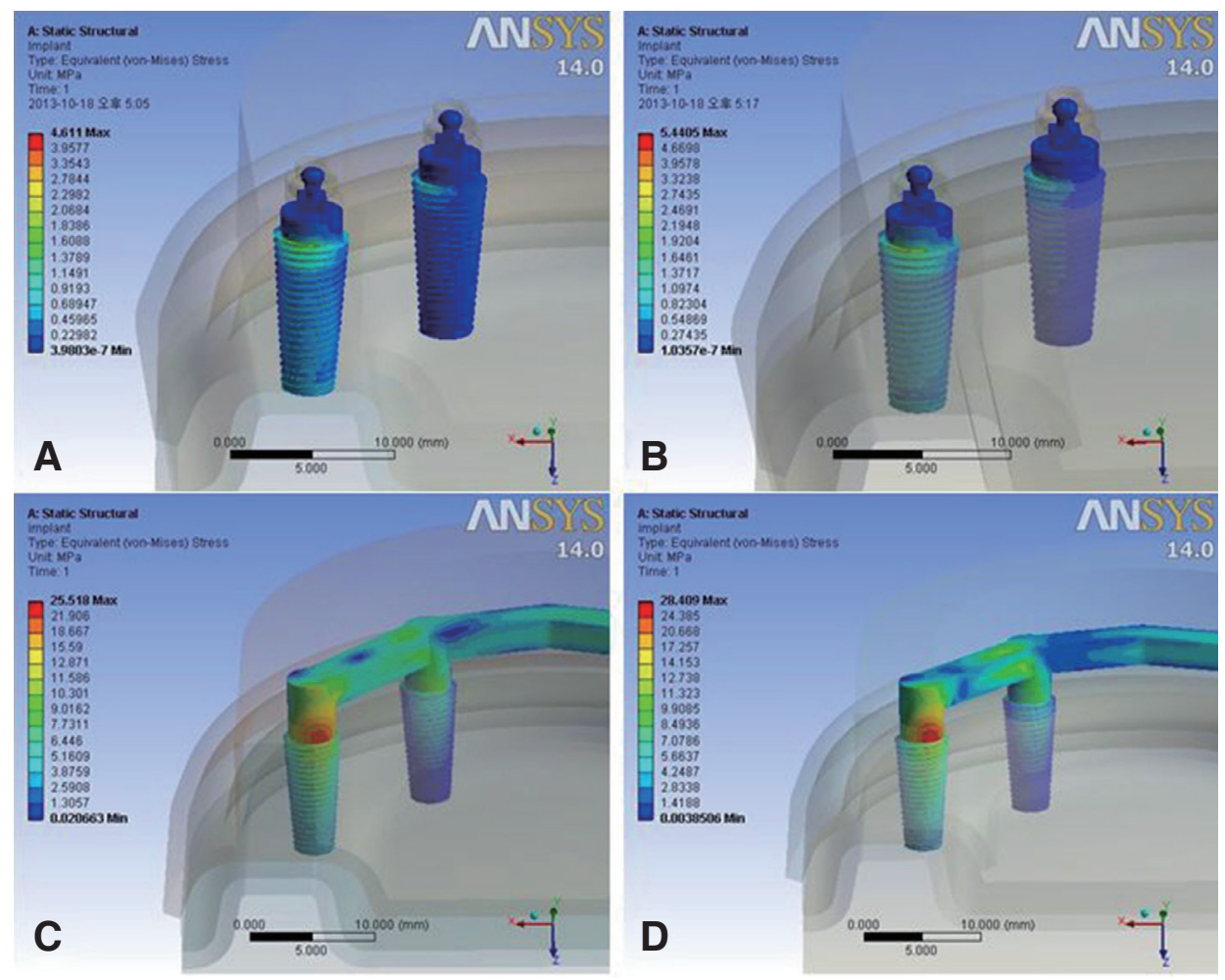

Fig. 5. Stress distribution on implant. (A) Ball-F, (B) Ball-P, (C) Bar-F, (D) Bar-P. 


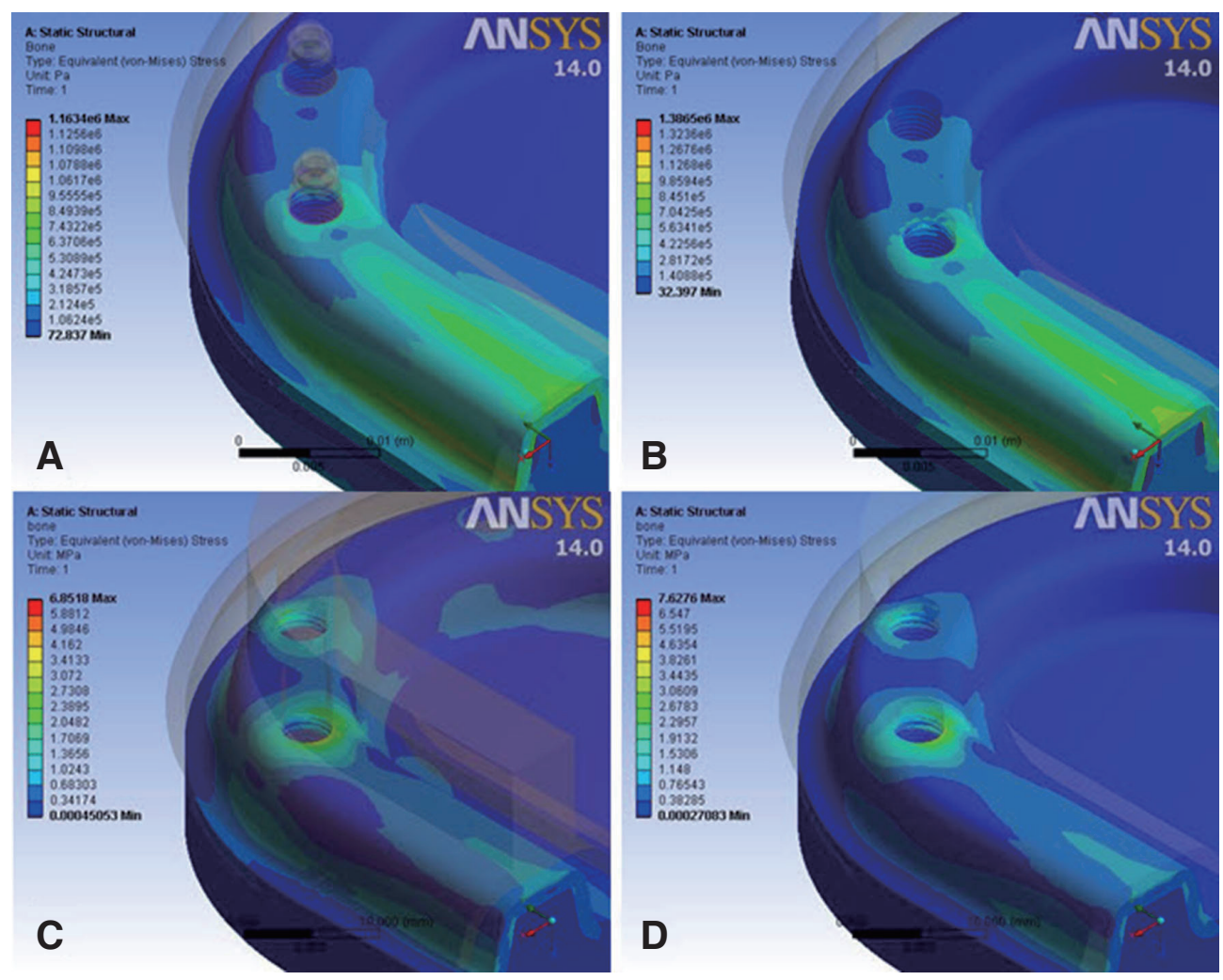

Fig. 6. Stress distribution on peri-implant bone. (A) Ball-F, (B) Ball-P, (C) Bar-F, (D) Bar-P.

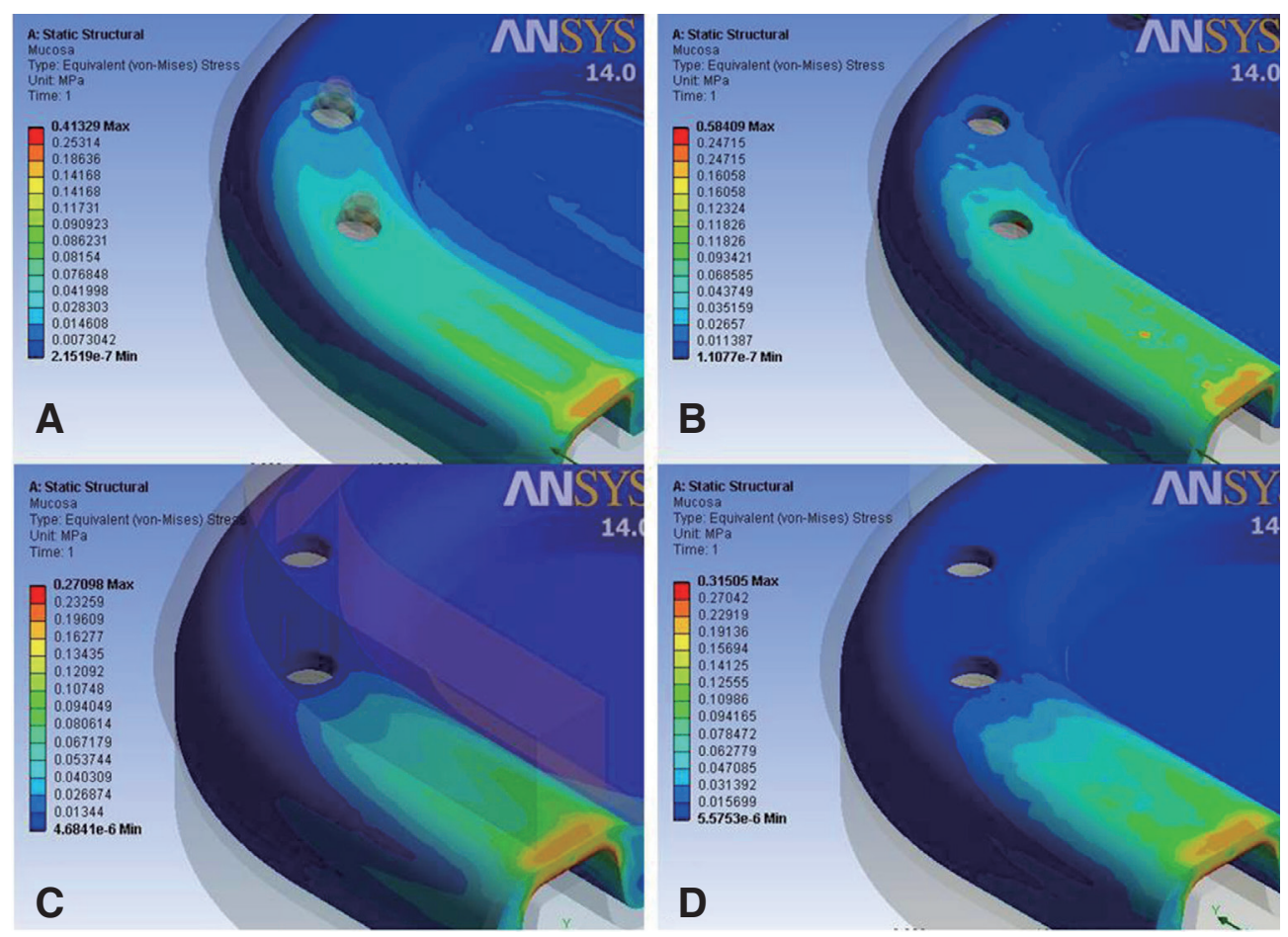

Fig. 7. Stress distribution on mucosa. (A) Ball-F, (B) Ball-P, (C) Bar-F, (D) Bar-P. 


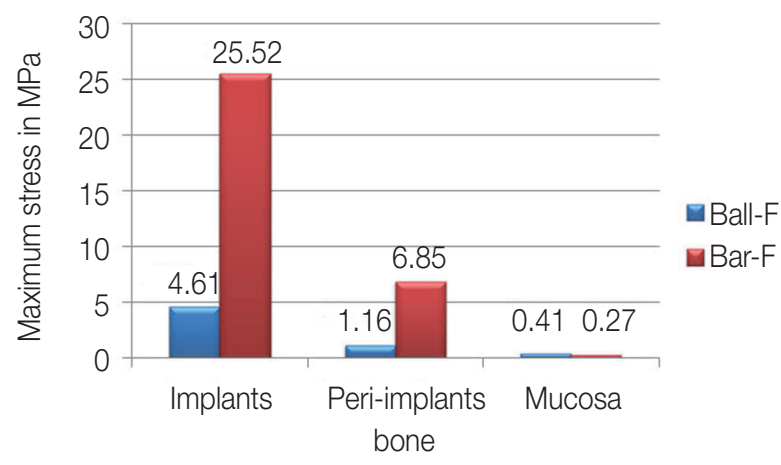

Fig. 8. Chart of maximum stress of Ball-F and Bar-F groups.

플란트 주위 골에서 바-유지장치를 사용한 실험군보다 더 낮은 최대 응력값을 보였으나, 점막에서는 더 높은 최 대 응력값을 보였다(Fig. 8, 9).

구개 피개 유무에 따른 응력분포에서는 유지장치의 종 류와 관계없이 구개를 완전히 피개한 실험군이 부분적으 로 피개한 실험군보다 임플란트와 임플란트 주위 골, 점 막에서 더 낮은 최대 응력값을 보였다(Fig. 8, 9).

\section{고찰}

일반적으로 임플란트와 관련된 응력 연구 방법으로는 전기저항 스트레인 게이지법, 광탄성 분석법, 유한요소분 석법이 있다. ${ }^{27}$ 본 연구에서 사용한 유한요소분석법은 컴 퓨터 소프트웨어를 통해 모델을 설계하기 때문에 수정 이 쉽고 구성요소에 다양한 물성과 이들 간의 관계에 다 양한 조건을 부여할 수 있다. 뿐만 아니라 원하는 부위에 발생한 응력과 변위 등의 정보를 확인할 수 있다는 장점 이 있다..$^{16,17}$

하악 임플란트 피개의치 수복은 임플란트 수나 유지장 치의 종류 등과 관계없이 높은 성공률을 보이나, 상악 임 플란트 피개의치는 불리한 해부학적 특징으로 인해 높은 실패율을 보이고 치료방법에 대한 논쟁이 많다. ${ }^{5-7} \mathrm{Wil}-$ liams 등 ${ }^{28}$ 은 상악 임플란트 피개의치의 적절한 유지와 지 지를 위해서는 최소 4 개의 임플란트가 필요하다고 하였 다. 또한, Mericske-Stern 등 ${ }^{4}$ 은 4 개 이상의 임플란트를 전체 악궁에 걸쳐 균둥하게 분포하게 식립하고 이를 연 결 고정하는 바 유지장치의 사용과 의치로 완전히 구개 를 피개할 것을 추천하였다. 하지만 경우에 따라 상악동 거상술을 피해 상악동 전방부에 다수의 임플란트를 식립

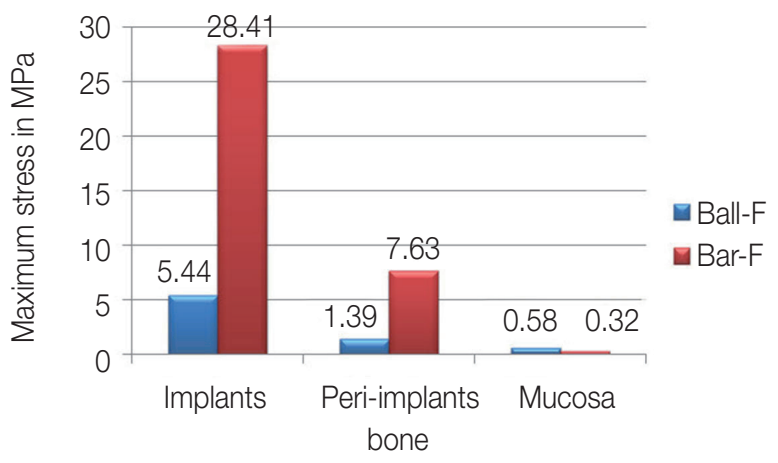

Fig. 9. Chart of maximum stress of Ball-P and Bar-P groups.

할 수 있다고 하였다. ${ }^{4}$ 따라서 본 연구에서는 상악동 전 방부에 4 개의 임플란트를 식립하고 임플란트 피개의치 를 제작했을 때를 가정해 유지장치 종류와 구개 피개 유 무에 따른 응력분포를 3차원 유한요소 분석을 통해 알아 보았다.

Ogata와 $\mathrm{Satoh}^{29}$ 는 의치 사용자의 최대 평균 저작력은 65 - 110 N이라고 하였기 때문에 이를 토대로 본 연구에 서는 편측 저작의 상황을 가정하여 우측 제 1 대구치 중심 와 부위에 $100 \mathrm{~N}$ 의 정적 하중을 가하였다.

모든 실험군에서 부하측 최후방 임플란트의 경부와 임 플란트 주위 피질골에서 최대 응력값이 나타났다. 이는 상악과 하악에서 수행된 많은 유한요소분석 결과와 비슷 한 경향을 보인다. ${ }^{16,17,25,26,30}$ 먼저, 부하측 최후방 임플란 트에 응력이 집중되는 이유는 캔틸레버를 가진 임플란트 고정성 보철물에 대한 유한요소분석 연구를 통해 추론할 수 있다. ${ }^{31}$ 보철물의 캔틸레버 부분에 수직적 하중이 가 해지면 상부구조물과 임플란트 복합체에 굽힘 모멘트가 발생하는데, 특히 치주인대 없이 골유착된 임플란트의 경우 하중 부위에 가까운 임플란트 원심부에 응력이 집 중된다. 본 연구에서 임플란트는 상악동 전방부에 식립 되어 있고 힘의 작용점이 제 1 대구치 부위이므로 피개의 치의 구치부가 임플란트에 캔틸레버로 작용하여 부하측 최후방 임플란트의 경부에 응력이 집중된 것으로 생각된 다. 또한, 최대 응력값이 임플란트 주위 피질골에서 나타 난 이유는 임플란트에 전달된 저작력이 주위의 피질골과 해면골로 전달될 때 탄성계수가 큰 피질골이 더 많은 응 력을 흡수하기 때문인 것으로 생각된다. ${ }^{32}$

본 연구에서 최대 응력값은 임플란트의 원심 구개측 부위에서 관찰되었다. 이는 하악 임플란트 피개의치에 
관한 Hussein ${ }^{18}$ 과 Hong 등 ${ }^{25}$ 의 연구와 비슷한 경향을 보 인다. Hong 등은 하악의 임플란트 위치에 따른 응력분포 에 관한 연구에서 임플란트 식립 위치가 소구치 부위에 서 측절치 부위로 즉, 전방으로 이동할수록 최대 응력값 이 나타나는 부위가 임플란트의 원심부에서 설측으로 이 동함을 보고하였다. 본 연구에서는 임플란트 식립 위치 를 상악동 전방부로 제한하였기에 최대 응력이 임플란트 의 원심부가 아닌 원심구개측에서 나타난 것으로 생각된 다.

모든 실험군에서 점막에서의 최대 응력값은 부하측 최 후방 치조제 부위에서 발생하였다. 이는 임플란트와 거 리가 멀수록 임플란트 지지보다는 조직지지 효과가 커지 기 때문으로 보인다.

구개 피개 유무와 상관없이 볼 유지장치는 바 유지장 치보다 임플란트와 임플란트 주위 골에서 더 낮은 최대 응력값을 보였으며, 반대로 점막에서는 더 큰 최대 응력 값을 보였다. 이는 상악에서 수행된 광탄성 분석 연구와 하악에서 수행된 유한요소분석 연구와 비슷한 경향을 보 인다. ${ }^{14,16}$ 볼과 같은 탄성 유지장치는 구성요소의 완압을 통해 의치의 움직임을 허용하여 임플란트와 임플란트 주 위 골로의 응력 집중을 감소시키지만, 상대적으로 탄성 이 없는(rigid) 밀드 바 유지장치는 의치의 움직임이 제한 되어 임플란트 및 임플란트 주위 골로 응력이 집중되는 것으로 생각된다. ${ }^{17}$ 하지만, 유지장치 선택에 있어 다양한 상황이 고려되어야 한다. 완압 성분을 가진 유지장치의 사용은 의치의 움직임이 더 많이 발생하고, 저작력을 잔 존치조제로 전달해 치조골의 흡수를 야기할 수도 있다. 또한, 볼과 같이 분리된 형태의 유지장치는 심한 골 흡수 로 잔존 치조제의 높이가 낮아 의치의 안정성이 부족한 경우 의치에 과도한 측방력이 가해지면 다른 임플란트로 응력이 분산되지 않아 특정 임플란트에 응력이 집중될 수 있다. ${ }^{11,33}$

유지장치의 종류와 관계없이 구개를 피개하지 않는 경 우가 피개한 경우보다 임플란트, 임플란트 주위 골 그리 고 점막의 최대 응력값이 높았다. 이는 상악 임플란트 피 개의치를 이용한 광탄성분석 연구 ${ }^{14,27}$ 와 유한요소분석 연 구 $^{30}$ 와 결과가 일치하는데, 이는 의치상 지지면적이 감소 함에 따라 임플란트와 의치상 하부 점막으로 전달되는 응력이 증가되었기 때문이라고 생각한다. 구개를 피개 하면 기능 시 점막에 의한 지지와 안정성이 향상되어 임 플란트로의 과도한 응력 집중을 막을 수 있다..$^{14,27,30}$ 그러 나, 대부분의 환자들은 불편감으로 인해 상악 의치의 구
개 피개를 원하지 않으며 ${ }^{34,35}$ Mericske-Stern 등 ${ }^{4}$ 은 상악 에 4 - 5개의 임플란트를 식립하고 바 유지장치로 견고하 게 연결한 경우 구개를 피개하지 않는 말굽형 설계가 가 능하다고 하였다.

본 연구에서 이용된 유한요소분석법은 응력이 발생하 는 부위와 양을 시각화 할 수 있어 직관적으로 평가하기 에 유리하지만, 점막과 골 등의 생역학과 구성요소의 물 성 및 구조의 단순화 등은 실제 상황을 재현하지 못하는 한계를 가지고 있다. 또한, 실제 임상상황에서는 본 실험 의 디자인대로 상악 전방부에 4 개의 임플란트를 대칭적 인 위치에 평행하게 식립하기 어렵다는 한계도 있다. 그 리고 임상적으로 가능한 다른 임플란트 식립 위치와 다 양한 유지장치를 활용한 피개의치 설계를 하여 구강 내 에서 일어날 수 있는 다양한 응력 발생에 관한 추가적인 연구도 필요할 것으로 사료된다.

\section{결론}

상악 무치악 환자에서 상악동 전방부에 4 개의 임플란 트를 식립하여 수복된 피개의치에서 유지장치 종류와 구 개 피개 유무에 따른 응력분포를 3 차원 유한요소분석을 통해 알아보았으며 다음과 같은 연구 결과를 얻었다.

임플란트와 임플란트 주위 골에서 최대 응력값은 부하 측 최후방 임플란트 경부와 주위 치밀골에서 관찰되었으 며 그 위치는 원심구개측 이었다.

볼 유지장치를 사용하는 군이 바 유지장치 군보다 임 플란트와 임플란트 주위 골에서 낮은 최대 응력값을 보 였으며 반대로 점막에서는 높은 최대 응력값을 보였다.

유지장치 종류와 상관없이 구개를 피개하는 실험군은 피개하지 않는 실험군보다 임플란트, 임플란트 주위 골 그리고 점막 모두에서 낮은 최대 응력값을 보였다.

본 연구의 한계 내에서 상악동 전방부에 4 개의 임플란 트를 식립하여 수복된 피개의치에서 바 유지장치보다는 볼 유지장치를 사용하고 구개를 완전히 피개하는 경우 임플란트와 임플란트 주위 골의 응력분산에 효과적임을 알 수 있었다.

\section{ORCID}

Jong-Hee Park https://orcid.org/0000-0001-9273-9205 Jeong-Jin Lee https://orcid.org/0000-0002-7381-5230 Yeon-Hee Park https://orcid.org/0000-0002-9183-9244 
Jae-Min Seo https://orcid.org/0000-0001-5095-4046

Kyoung-A Kim https://orcid.org/0000-0002-2923-5351

\section{References}

1. Jemt T, Book K, Karlsson S. Occlusal force and mandibular movements in patients with removable overdentures and fixed prostheses supported by implants in the maxilla. Int J Oral Maxillofac Implants 1993;8:301-8.

2. Lewis S, Sharma A, Nishimura R. Treatment of edentulous maxillae with osseointegrated implants. J Prosthet Dent 1992;68:503-8.

3. Naert I, Quirynen M, Theuniers G, van Steenberghe D. Prosthetic aspects of osseointegrated fixtures supporting overdentures. A 4-year report. J Prosthet Dent 1991;65:671-80.

4. Mericske-Stern RD, Taylor TD, Belser U. Management of the edentulous patient. Clin Oral Implants Res 2000;11 Suppl 1:108-25.

5. Engquist B, Bergendal T, Kallus T, Linden U. A retrospective multicenter evaluation of osseointegrated implants supporting overdentures. Int J Oral Maxillofac Implants 1988;3:129-34.

6. Hutton JE, Heath MR, Chai JY, Harnett J, Jemt T, Johns RB, McKenna S, McNamara DC, van Steenberghe D, Taylor R, et al. Factors related to success and failure rates at 3-year follow-up in a multicenter study of overdentures supported by Brånemark implants. Int J Oral Maxillofac Implants 1995;10:3342.

7. Jemt T, Chai J, Harnett J, Heath MR, Hutton JE, Johns RB, McKenna S, McNamara DC, van Steenberghe D, Taylor R, Watson RM, Herrmann I. A 5-year prospective multicenter follow-up report on overdentures supported by osseointegrated implants. Int J Oral Maxillofac Implants 1996;11:2918.

8. Brunski JB, Puleo DA, Nanci A. Biomaterials and biomechanics of oral and maxillofacial implants: current status and future developments. Int J Oral Maxillofac Implants 2000;15:15-46.

9. Hoshaw SJ, Brunski JB, Cochran GV. Mechanical Loading of Brånemark Implants Affects Interfacial Bone Modeling and Remodeling. Int J Oral Maxil- lofac Implants 1994;9:345-60.

10. Lavelle CL. Biomechanical considerations of prosthodontic therapy: the urgency of research into alveolar bone responses. Int J Oral Maxillofac Implants 1993;8:179-85.

11. Närhi TO, Hevinga M, Voorsmit RA, Kalk W. Maxillary overdentures retained by splinted and unsplinted implants: a retrospective study. Int J Oral Maxillofac Implants 2001;16;259-66.

12. Quirynen M, Naert I, Van Steenberghe D. Fixture design and overload influence marginal bone loss and future success in the Brånemark ${ }^{\circledR}$ system. Clin Oral Implants Res 1992;3:104-11.

13. Shafie H. Principles of attachment selection. Clinical and Laboratory Manual of Implant Overdentures. Ames, Iowa; Blackwell; 2007.

14. Ochiai KT, Williams BH, Hojo S, Nishimura R, Caputo AA. Photoelastic analysis of the effect of palatal support on various implant-supported overdenture designs. J Prosthet Dent 2004;91:421-7.

15. Tokuhisa M, Matsushita Y, Koyano K. In Vitro Study of a Mandibular Implant Overdenture Retained with Ball, Magnet, or Bar Attachments: Comparison of Load Transfer and Denture Stability. Int J Prosthodont 2003;16:128-34.

16. Barão VAR, Assunção WG, Tabata LF, Delben JA, Gomes EA, de Sousa EA, Rocha EP. Finite element analysis to compare complete denture and implant-retained overdentures with different attachment systems. J Craniofac Surg 2009;20:1066-71.

17. Tanino F, Hayakawa I, Hirano S, Minakuchi S. Finite element analysis of stress-breaking attachments on maxillary implant-retained overdentures. Int J Prosthodont 2007;20:193-8.

18. Hussein MO. Stress-strain distribution at bone-implant interface of two splinted overdenture systems using 3D finite element analysis. J Adv Prosthodont 2013;5:333-40.

19. Giddon DB, Dreisbach ME, Pfaffman C, Manly RS. Relative abilities of natural and artificial dentition patients for judging the sweetness of solid foods. J Prosthet Dent 1954;4:263-8.

20. Shannon IL, Terry JM, Nakamoto RY. Palatal coverage and parotid flow rate. J Prosthet Dent 1970;24:601-7.

21. Strain JC. The influence of complete dentures 
upon taste perception. J Prosthet Dent 1952;2:60-7.

22. Palmqvist S, Sondell K, Swartz B. Implant-supported maxillary overdentures: outcome in planned and emergency cases. Int J Oral Maxillofac Implants 1994;9:184-90.

23. Kim HS, Shin SW. Three-dimensional analysis of the normal dentition and edentulous maxilla of Koreans. J Korean Acad Prosthodont 2005;43:191203.

24. Kydd WL, Daly CH, Wheeler 3rd JB. The thickness measurement of masticatory mucosa in vivo. Int Dent J 1971;21:430-41.

25. Hong HR, Pae A, Kim Y, Paek J, Kim HS, Kwon KR. Effect of implant position, angulation, and attachment height on peri-implant bone stress associated with mandibular two-implant overdentures: a finite element analysis. Int J Oral Maxillofac Implants 2012;27:69-76.

26. Osman RB, Elkhadem AH, Ma S, Swain MV. Finite element analysis of a novel implant distribution to support maxillary overdentures. Int J Oral Maxillofac Implants 2013;28:1-10.

27. Je HJ, Jeon YC, Jeong CM, Lim JS, Hawong JS. Effect of anchorage systems and palatal coverage of denture base on load transfer with maxillary implant-supporting overdentures: A three-dimensional photoelastic stress analysis. J Korean Acad Prosthodont 2004;42:397-411.

28. Williams BH, Ochiai KT, Hojo S, Nishimura R, Caputo AA. Retention of maxillary implant overdenture bars of different designs. J Prosthet Dent 2001;86:603-7.
29. Ogata K, Satoh M. Centre and magnitude of vertical forces in complete denture wearers. J Oral Rehabil 1995;22:113-9.

30. Kim MJ, Hong SO. Finite element analysis on stress distribution of maxillary implant-retained overdentures depending on the Bar attachment design and palatal coverage. J Adv Prosthodont 2016;8:85-93.

31. Sertgöz A, Güvener S. Finite element analysis of the effect of cantilever and implant length on stress distribution in an implant-supported fixed prosthesis. J Prosthet Dent 1996;76:165-9.

32. Yokoyama S, Wakabayashi N, Shiota M, Ohyama T. Stress analysis in edentulous mandibular bone supporting implant-retained 1-piece or multiple superstructures. Int J Oral Maxillofac Implants 2005;20: 578-83.

33. Vafaei F, Khoshhal M, Bayat-Movahed S, Ahangary AH, Firooz F, Izady A, Rakhshan V. Comparative stress distribution of implant-retained mandibular ball-supported and bar-supported overlay dentures: a finite element analysis. J Oral Implantol 2011;37: 421-9.

34. Zembic A, Tahmaseb A, Wismeijer D. Within-subject comparison of maxillary implant-supported overdentures with and without palatal coverage. Clin Implant Dent Relat Res 2015;17:570-9.

35. Al-Zubeidi MI, Alsabeeha NH, Thomson WM, Payne AG. Patient satisfaction with maxillary 3-implant overdentures using different attachment systems opposing mandibular 2-implant overdenture. Clin Implant Dent Relat Res 2012;14:696-707. 


\title{
상악 임플란트 피개의치에서 유지장치 종류와 구개 피개 유무에 따른 응력분포에 대한 유한요소분석
}

\author{
박종희 ${ }^{1}$ 개원의, 왕원곤 ${ }^{1}$ 대학원생, 박연희 ${ }^{1}$ 전공의, 이정진 ${ }^{1}$ 조교수, 서재민 ${ }^{1}$ 부교수, 김경아 ${ }^{2 *}$ 조교수 \\ ${ }^{1}$ 전북대학교 치의학전문대학원 치과보철학교실 및 구강생체과학연구소 \\ ${ }^{2}$ 을지대학교 의과대학 치과학교실
}

목적: 상악 임플란트 피개의치에서 유지장치 종류와 구개 피개 유무에 따른 응력분포를 3차원 유한요소분석법을 통해 알아보고자 한다.

연구 재료 및 방법: $\mathrm{CAD}$ 를 이용하여 전방부에 4개의 임플란트를 식립한 4종류의 상악 임플란트 피개의치에 대한 3차원 모델을 디자인하였다. 1) Ball-F: 볼 유지장치를 사용하고 구개를 피개한 군, 2) Ball-P: 볼 유지장치를 사용하고 구개를 피개하지 않은 군, 3) Bar-F: 바 유지장치를 사용하고 구개를 피개한 군, 4) Bar-P: 바 유지장치를 사용하고 구개를 피개 하지 않은 군. 응력분석은 유한요소 분석 프로그램인 ANSYS Workbench Ver. 14를 사용하였으며, 편측 저작의 상황을 고려하여 우측 제 1 대구치에 $100 \mathrm{~N}$ 의 정적하중을 적용하여 임플란트, 임플란트 주위 골, 점막에 발생하는 최대 응력값을 기록하였다.

결과: 볼 유지장치를 사용한 군이 바 유지장치를 사용한 군보다 임플란트 및 임플란트 주위골에 발생하는 최대 응력값 이 작았다. 하지만 점막에서의 최대 응력값은 그 반대로 나타났다. 구개를 피개하면 유지장치의 종류와 무관하게 임플란 트, 임플란트 주위 골, 점막 모두에서 최대응력값이 작아졌다.

결론: 본 연구의 한계 내에서 상악동 전방부에 4 개의 임플란트를 식립하여 수복된 피개의치에서 바 유지장치보다는 볼 유지장치를 사용하고 구개를 완전히 피개하는 경우가 임플란트와 임플란트 주위 골의 응력분산에 효과적이다.

(구강회복응용과학지 2020;36(2):70-9)

주요어: 임플란트 피개의치; 유지장치; 3차원 유한요소분석

*교신저자: 김경아

(34824) 대전광역시 중구 계룡로 771번지 77 을지대학교 의과대학 치과학교실

Tel: 042-611-3486 | Fax: 042-611-3776 | E-mail: dentka@eulji. ac. kr

접수일: 2020년 3월 17일 | 수정일: 2020년 5월 5일 | 채택일: 2020년 5월 21일 